\title{
Multiple periannular defects after an inadequate mitral valve repair procedure and unsuccessful redo valve surgery with pericardial patches in an elderly patient
}

\author{
Cüneyt Toprak ${ }^{1}$, Anil Avci ${ }^{1}$, Mehmed Yanartas², Mehmet Mustafa Tabakci ${ }^{1}$, Emrah Acar ${ }^{1}$, \\ Mehmet Ozkan ${ }^{1}$
}

${ }^{1}$ Department of Cardiology, Kosuyolu Kartal Heart Training and Research Hospital, Istanbul, Turkey

${ }^{2}$ Cardiovascular Surgery, Kosuyolu Kartal Heart Training and Research Hospital, Istanbul, Turkey

Kardiochirurgia i Torakochirurgia Polska 2016; 13 (2): 140-142

\begin{abstract}
The fastest growing demographic group in Europe and America is the elderly, and significant mitral regurgitation is very prevalent in this population. At present, with mitral valve surgery in elderly individuals gaining greater acceptance worldwide, the question whether to repair or replace the valve remains controversial. Recent studies have demonstrated the safety, feasibility, and durability of repair over replacement in elderly patients. Herein, we report the case of an elderly patient who underwent surgical re-interventions on the mitral valve following an unsuccessful mitral valve repair procedure.

Key words: bioprosthetic valve, elderly patients, mitral valve repair.
\end{abstract}

\section{Case report}

A 75-year-old man was admitted to an outpatient clinic with exertional dyspnea and palpitation. His medical history included end-stage chronic renal failure and hypertension. Electrocardiographic examination demonstrated atrial fibrillation with a rapid ventricular rate. Transthoracic echocardiography (TTE) revealed prolapse of the posterior leaflet with severe regurgitation directed anteriorly (Fig. 1). Following medical stabilization, transesophageal echocardiography (TEE) was conducted. Surgical valve repair was feasible, and our heart team decided to perform it. The surgery included resection of the P2 scallop of the posterior leaflet, neochordal implantation, and implantation of a 34-mm mitral annuloplasty ring. However, mitral valve repair failed. Therefore, we decided to use a 31- $\mathrm{mm}$ bioprosthetic valve in consideration of the age of the patient. The valve replacement without mitral leaflets preservation was successfully done. The patient's condition was good in

\section{Streszczenie}

Populacja osób starszych jest najszybciej powiększającą się grupą demograficzną w Europie i Ameryce; istotna niewydolność zastawki mitralnej występuje bardzo często u tych pacjentów. Obecnie, przy rosnącej akceptacji zabiegów chirurgicznych na zastawkach mitralnych u osób starszych, kontrowersyjne pozostaje pytanie, czy zastawkę należy naprawić czy wymienić. W niedawno opublikowanych pracach przedstawiono dobre wyniki w zakresie wykonalności, bezpieczeństwa i trwałości naprawy zastawki w porównaniu z wymianą u starszych pacjentów. W tej pracy przedstawiamy przypadek starszego pacjenta, który został poddany powtórnym interwencjom chirurgicznym w obrębie zastawki mitralnej po nieudanym zabiegu jej naprawy.

Słowa kluczowe: zastawka biologiczna, starsi pacjenci, naprawa zastawki mitralnej.

postoperative follow-up. Three weeks later, he was again admitted to the emergency service with severe dyspnea. Transthoracic echocardiography was performed, detecting paravalvular leakage. Three-dimensional TEE revealed periannular defects on the medial and anterior parts of the bioprosthetic valve and concomitant severe mitral insufficiency (Fig. 2). The heart team decided that a second operation was necessary. The periannular defects were observed intraoperatively (Fig. 3) and were closed successfully with two pericardial patches. After the operation, the patient's condition was good with regard to both functioning and symptoms. Again, the patient was discharged with medications. After 2 weeks, the patient was again admitted to the emergency room with pulmonary edema. Emergency TTE was performed, revealing paravalvular leakage. After the medical stabilization of the patient, 3-dimensional TEE was electively performed and demonstrated the presence of leakage in the patched region of the valve (Fig. 4).

Address for correspondence: Cüneyt Toprak MD, Merdivenköy Mah., Merdivenköy yolu Cd., No. 25/13, 34732 Kadıköy, Istabul, Turkey, phone: +90 506 2978656, fax: +90 216 4596321, e-mail: cuneytoprak@hotmail.com 


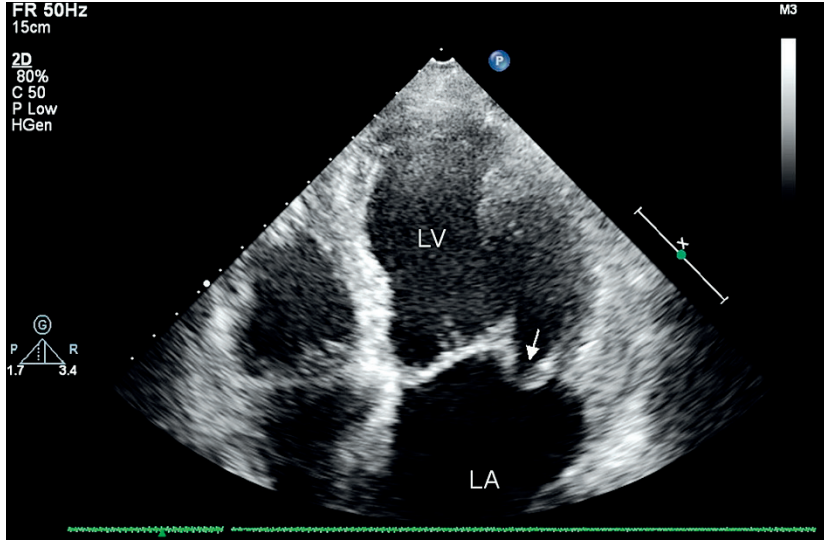

Fig. 1. Transthoracic apical four-chamber view showing posterior mitral valve prolapse (arrow) and dilated left heart chambers

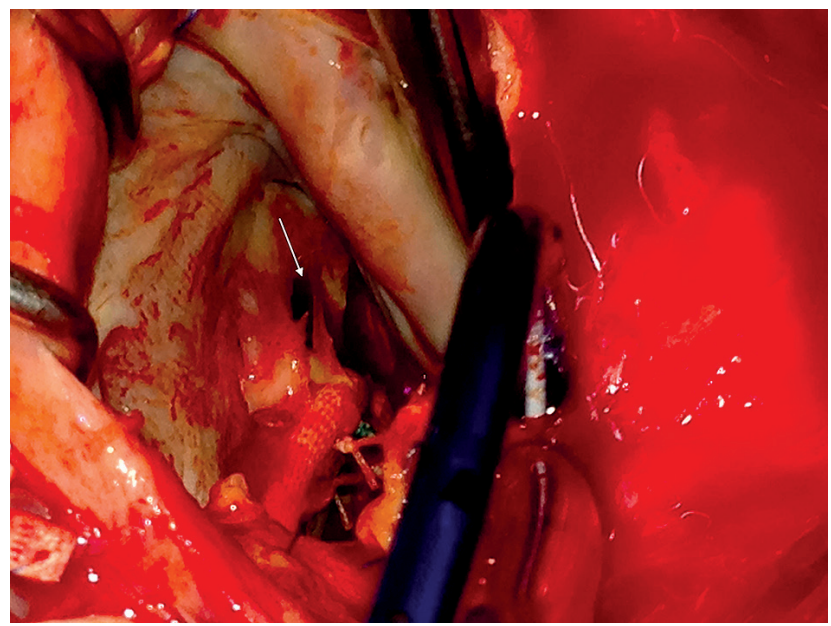

Fig. 3. Intraoperative view of periannular defect

The patient refused any interventional treatment or surgical correction, so we decided to follow up the patient medically.

\section{Discussion}

With regard to the management of mitral insufficiency caused by degenerative mitral valve disease, repair is be-
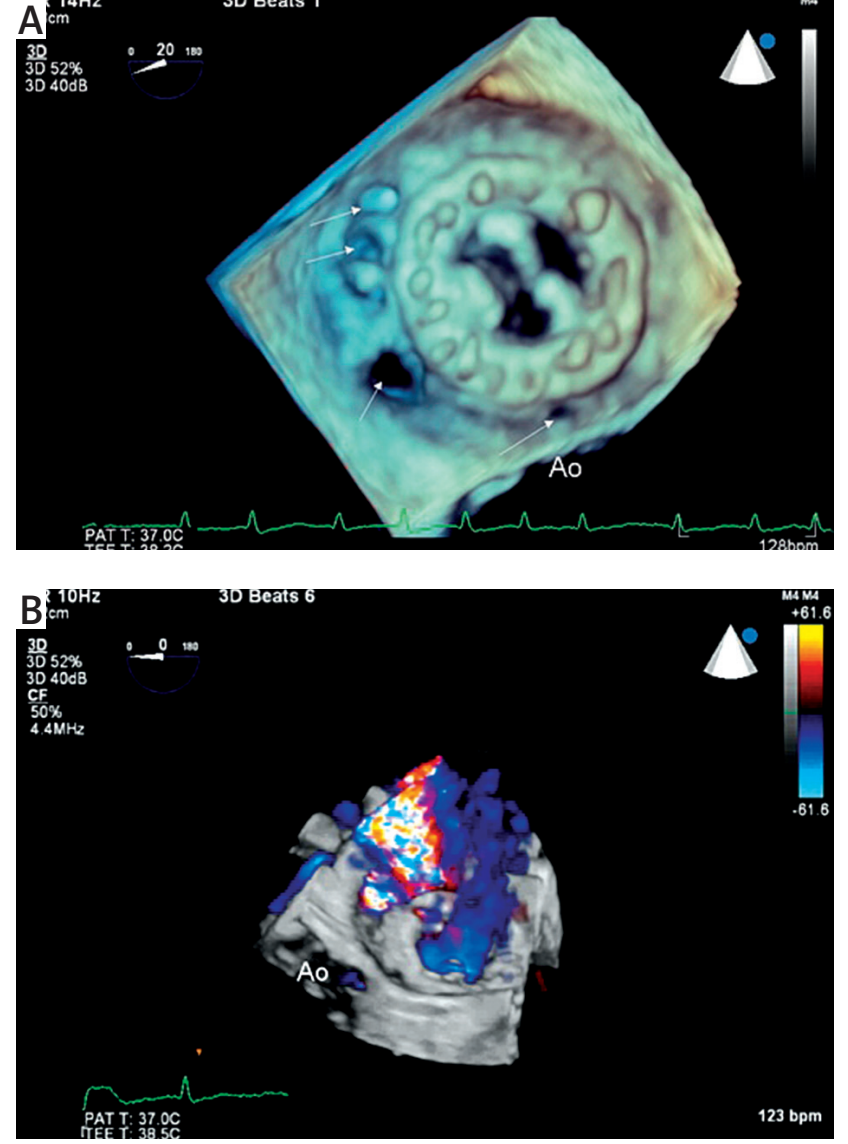

Fig. 2. Three-dimensional transesophageal enface view showing anterior and medial periannular defects (arrows) (A). Full volume color view showing severe regurgitation jets (B)

coming more popular than replacement in all age groups, offering very good short- and long-term results; survival after mitral valve repair among elderly patients is equivalent to that in a normal age-matched population [1, 2]. Older patients, however, are often considered to be unsuitable candidates for mitral repair because of comorbidities, shorter life expectancy, the perception that they may not
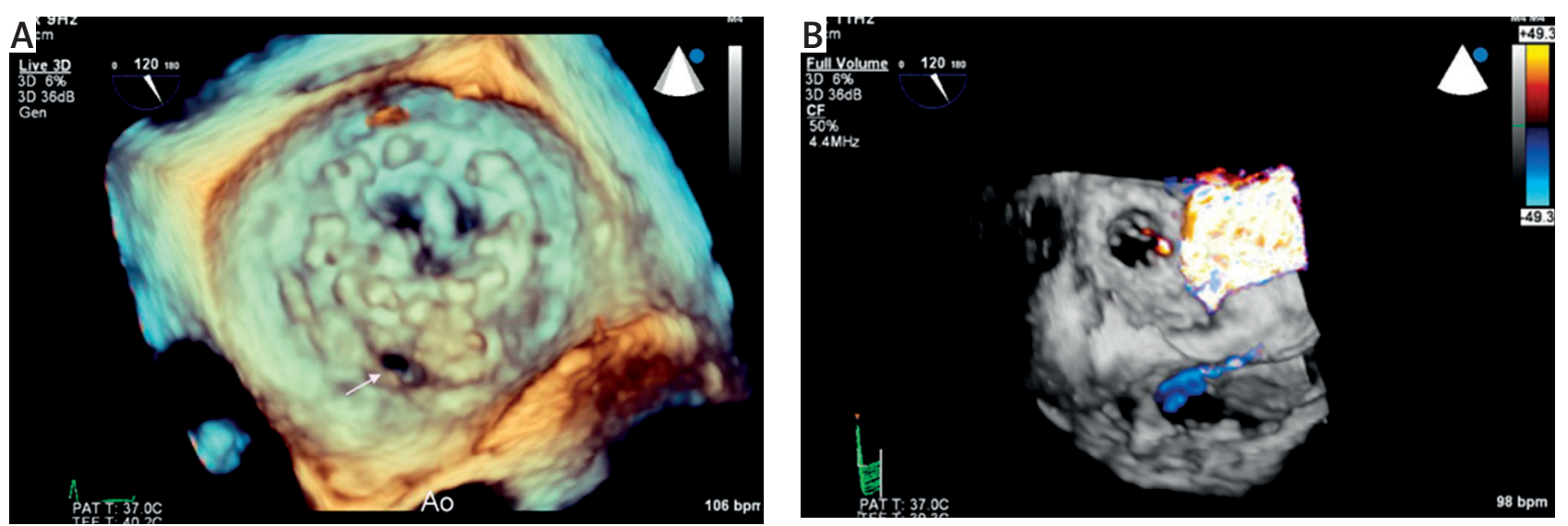

Fig. 4. Three-dimensional transesophageal enface view showing anterior periannular defect originating from pericardial patching site (arrow) (A). Full volume color view showing severe regurgitation jet (B) 
tolerate a return to cardiopulmonary bypass due to inadequate mitral valve repair, and the fact that valve repair can be difficult $[3,4]$. Moreover, some surgeons suggest that mitral valve repair provides no benefit in patients older than 60 years [5]. In the case of valve replacement, the use of a bioprosthesis is a better choice for elderly patients because the associated mortality and morbidity rates are lower than those associated with a mechanical prosthesis [6]. In this report, we present a patient in whom a series of surgical procedures were performed, starting with an unsuccessful repair procedure and concurrent implantation of a bioprosthesis; after some time, a peri-annular defect was revealed and closed with pericardial patches during a second operation, but the procedure failed. We think that there are two reasons for this complication: the major problem was the patient's age and comorbidities, resulting in very fragile mitral periannular tissue; and the other reason was the failed mitral repair procedure which might have caused tissue damage before the mitral valve replacement. Also, there were no organic predispositions, such as endocarditis, that might result in severe complications. At present, as mitral valve surgery in elderly patients is gaining greater acceptance worldwide, the question whether to repair or replace the valve remains controversial.

We have presented a case of complicated mitral valve repair in an elderly patient. We conclude that replacement of the mitral valve with a bioprosthesis in cases of mitral insufficiency caused by degenerative mitral valve disease may be a good alternative to mitral valve repair in elderly patients due to the presence of comorbidities and shorter life expectancy.

\section{Disclosure}

Authors report no conflict of interest.

\section{References}

1. Chikwe J, Goldstone AB, Passage J, Anyanwu AC, Seeburger J, Castillo JG, Filsoufi F, Mohr FW, Adams DH. A propensity score-adjusted retrospective compression of early and mid-term results of mitral valve repair versus replacement in octogenarians. Eur Heart J 2011; 32: 618-626.

2. Gillinov AM, Blackstone EH, Nowicki ER, Slisatkorn W, Al-Dossari G, Johnston DR, George KM, Houghtaling PL, Griffin B, Sabik JF 3rd, Svensson LG. Valve repair versus replacement for degenerative mitral valve disease. I Thorac Cardiovasc Surg 2008; 135: 885-893.

3. Gogbashian A, Sepic J, Soltesz EG, Nascimben L, Cohn LH. Operative and longterm survival of elderly is significantly improved by mitral valve repair. Am Heart J 2006; 151: 1325-1333.

4. Cohn LH, Kowalker W, Bhatia S, DiSesa VJ, St John-Sutton M, Shemin RJ, Collins JJ. Comparative morbidity of mitral valve repair versus replacement for mitral regurgitation with and without coronary artery disease. 1988. Updated in 1995. Ann Thorac Surg 1995; 60: 1452-1453.

5. Thourani VH, Weintraub WS, Guyton RA, Jones EL, Williams WH, Elkabbani $\mathrm{S}$, Craver JM. Outcomes and long-term survival for patients undergoing mitral valve repair versus replacement: effect of age and concomitant coronary. Circulation 2003; 108: 298-304.

6. Nishida T, Sonoda H, Oishi Y, Tanoue Y, Nakashima A, Shiokawa Y, Tominaga R. Mechanical prosthesis is reasonable for mitral valve replacement in patients approximately 65 years of age. Ann Thorac Surg 2013; 96: 1614-1620. 